\title{
Modeling the Transport of Potassium Level in Yarmouk Basin Using SWMS-3D Model
}

\author{
ALAEDDIN TAHBOUB, RAKAD TA'ANY*, NEDAL AL OURAN, \\ NASER ALMANASEER and MUATH AZMI
}

Faculty of Agricultural Technology, Al Balqa' Applied University, Department of Water Resources and Environmental Management Al-Salt 19117 Jordan.

http://dx.doi.org/10.12944/CWE.9.3.13

(Received: November 09, 2014; Accepted: December 02, 2014)

\begin{abstract}
Yarmouk Basin is a transboundary basin shared between Jordan and Syria. Only 1,426 km² of the basin total area $\left(7,242 \mathrm{~km}^{2}\right)$ lie within the borders of Jordan. The study area is characterized by altitudes varying from more than $1,150 \mathrm{~m}$ in the south to about $200 \mathrm{~m}$ below sea level in the northwest. The contamination of groundwater by potassium in the upper aquifer is prevailing in the west part of the Yarmouk Basin. The concentration of potassium ranges between 0-163 mg/l with an average of $7 \mathrm{mg} / \mathrm{L}$. This study aims to evaluate potassium concentrations in the upper aquifer of this basin and to predict future potential of this ion and to find whether these concentrations agree with the safe range or not. The main data were collected from the Ministry of Water and Irrigation (MWI). The chemical properties of groundwater wells were analyzed at Al Balqa' Applied University laboratories and compared with the Jordanian standards. The spatial and temporal changes of potassium were studied as a pollution indicator. Pollution of groundwater level maps were generated using a Geostatistical program GS version 5.1, with the Kriging interpolation method. It was concluded that an increase in potassium concentrations for the decade ahead (2020) was noticed. But tremendous rise between 2020-2030, can be either attributed to intensive cultivation which increases use of organic and chemical fertilizers, where both are sources of potassium, or to over abstraction of groundwater which enhances potassium along with other pollutants concentrations in groundwater of Yarmouk Basin upper aquifer.
\end{abstract}

Key words: Irrigation, Aquifer, Pollution, Potassium, Groundwater, Contamination, Toxicity.

\section{INTRODUCTION}

Jordan has a hot, dry climate characterized by long, hot, dry summers and short, cool winters. The climate is influenced by Jordan's location between the subtropical aridity of the Arabian desert areas and the subtropical humidity of the eastern Mediterranean area. About 70 percent of the average rainfall in the country falls between November and March, (JMD, 2010). Water scarcity will become an even greater problem over the next two decades as the population doubles and climate change potentially makes precipitation more uncertain and variable.
Jordan is a prime country to examine due to its even more dire lack of fresh water resources as compared with its regional neighbors that are more blessed with water or have the wealth to create it with desalination technology. Jordan is considered the third driest country in the world, which is not surprising due to the desert environment that encompasses $92 \%$ of its land area (Denny et al., 2008). Its per capita share of renewable water resources is just $140 \mathrm{~m} 3$ per year, which is expected to fall to $90 \mathrm{~m} 3$ per year by the year 2025, (Nortcliff et al., 2008).

Groundwater quality has been deteriorating in many parts of Jordan in recent years due to 
rapid development, expansion of agriculture, and industrialization. The country, however cannot afford a situation in which precious water resources are lost due to pollution from a wide variety of point and non-point sources including agricultural, domestic, and industrial. (Awawdeh, 2009).

The presence of joints and fractures mainly in the northern and western basin, makes the aquifer in these locations more vulnerable to contamination as contaminated water can easily reach and mix with the groundwater. Many springs emerging from the upper aquifer (B4/B5) show chemical or bacteriological contamination, (Chilton, 2006).

Treated/untreated wastewater is another major source of groundwater pollution, which is indicated by the presence of bacteriological contamination in the wells surrounding Ar Ramtha wastewater treatment plant. Total coliform content up to $1600 \mathrm{MPN} / 100 \mathrm{ml}$, and E.coli content of $500 \mathrm{MPN} / 100 \mathrm{ml}$ were recorded. Rock/soil-water interaction plays an important role in the modification of the groundwater chemistry, especially water hardness, (Obeidat et al., 2012) and (Abu-Jaber and Kharabsheh, 2008) .

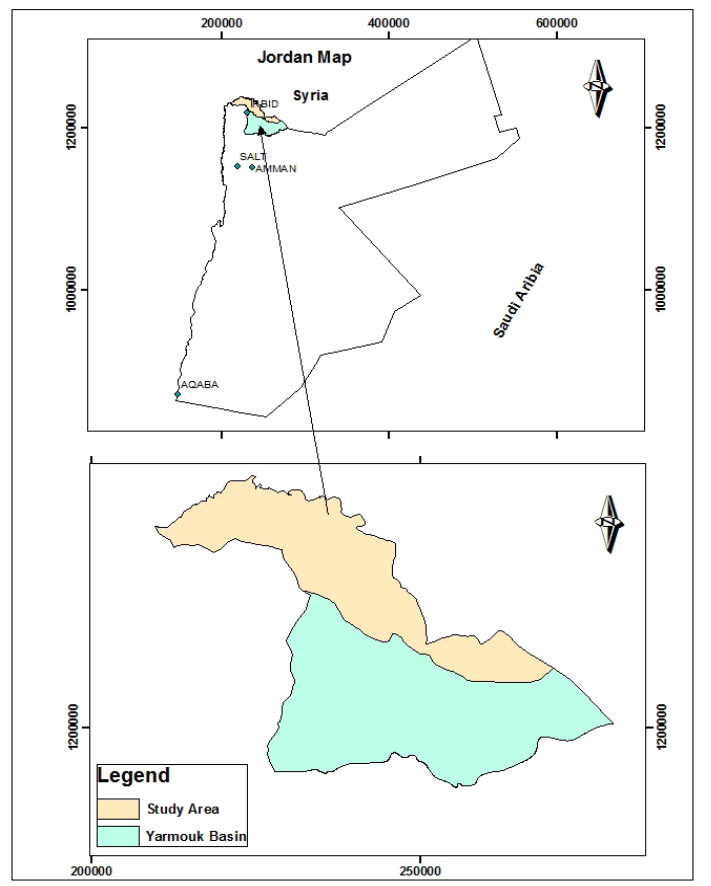

Fig. 1: Location map of the Yarmouk basin
Contamination of groundwater by potassium is prevailing in the west part of the Yarmouk Basin. The concentration of potassium ranges between $0-163 \mathrm{mg} / \mathrm{l}$ with an average of $7 \mathrm{mg} / \mathrm{L}$, which is below the recommended standard of the World Health Organization (12 mg /L), (WHO, 2011). Rivers generally contain about 2-3 ppm potassium. Calcium rich granite contains up to $2.5 \%$ potassium. This element is mainly present as $\mathrm{K}^{+}(\mathrm{aq})$ ions in water. Potassium occurs in various minerals, from which it may be dissolved through weathering processes. Orthopogenic wastewater releases are hazardous when discharged on surface water, and that is difficult to purify.

Potassium is weakly hazardous in water, but it does spread pretty rapidly, because of its relatively high mobility and low transformation potential. Potassium toxicity is usually caused by other components in a compound, for example cyanide in potassium cyanide. The intake of a number of potassium compounds may be particularly harmful. At high doses potassium chloride interferes with nerve impulses, which interrupts with virtually all bodily functions and mainly affects heart functioning. When potassium $\left(\mathrm{K}^{+}\right)$fertilizers are applied to soil, $\mathrm{K}^{+}$ is subject to displacement through the soil profile.

The application of $\mathrm{K}^{+}$fertilizers to sandy soils with low clay content and small buffer capacity, in which $\mathrm{K}^{+}$does not interact strongly with the soil matrix, results in localized increases in $\mathrm{K}^{+}$concentration in the soil solution. Losses of $\mathrm{K}^{+}$ depend on the concentration of calcium $\left(\mathrm{Ca}^{+2}\right)$ as a competing ion in the leaching water and the amount of water that passes through the soil. Large amounts of $\mathrm{K}^{+}$are leached from soils in areas where crops are irrigated with water that contains significant concentrations of $\mathrm{Ca}^{+2}$ and other cations, (Kolahchi, 2006).

Yarmouk basin is the main supplier of domestic and irrigation water for Irbid, northern Jordan Valley and Amman. Therefore, Yarmouk basin is of special interest and the purposes of this study are: To predict the potassium level in upper aquifer (Rijam- B4) using SWMS_3D and to give some recommendations for the decision makers and users for the water quality management options. 


\section{MATERIALS AND METHODS}

\section{Site Description}

Yarmouk River flows at the borders of Syria and Jordan and joins the Jordan River. Yarmouk River drains both flood and base flows of Jordanian and Syrian territories. The Yarmouk Basin is located in the northern part of Jordan. Seventy-five percent of this basin lies in Syria. In Jordan, the basin is located between coordinates 210 to $270 \mathrm{E}$ and 210 to 240 $\mathrm{N}$ (according to Palestine Grids), covering an area of about 1,426 km², (MWI, 2012), Figure 1.

Northern Jordan between the Zarqa and Yarmouk rivers, (Figure 1) is a key area on the hydrological map of the country. The adjacent mountain areas and heights, which stand at 1,200 m above sea level, are the highest uplands to the east of the Jordan Rift Valley. Yarmouk River flows at the borders between Syria and Jordan, which delineates the Northern boundary of the study area, whereas the Jordan River represents the western boundary. The Yarmouk River originates from Jabel Al-Arab (Syria) and drains from the Jordanian and Syrian territories. Al-Wehda Dam was constructed in 2006 between Jordan and Syria across this river,

The dam supplies Jordan with about, $110 \mathrm{MCM} / \mathrm{yr}$ of potable water. Water quality of the springs, which discharge into the dam, is of great importance for determining the usability of the stored waters. Yarmouk River Basin is highly recharged by rainfall and having good water quality. It is also the main supplier of domestic and irrigation water for Irbid, northern Jordan Valley and Amman. The groundwater quality of the Yarmouk basin reflects the land uses within and beyond the basin area, the former is still restricted to rainfed and some irrigated agriculture, (Al-Taani, et al., 2012) and (Batayneh, 2010).

\section{Data collection and Analysis}

The collection of the basic data involves a review of relevant literature to develop a geological database consisting of geomorphologic, geological, geophysical, and soil data. It also includes gathering of detailed information on the previous studies and data from wells drilled for various water, mineral exploration targets, and pollution concentrations in wells water. Data collection will also include the base maps, satellite images, aerial photographs, and geological maps, (MWI, 2012). The hydrological data includes well location, well depth, well status, aquifer code, water level, test date, well yield, pumping duration, static water level, groundwater salinity, drilling initiation and aquifers properties.

The Chemical properties of water wells were analyzed at the laboratories of Al Balqa' Applied University and compared with the Jordanian standards. The spatial and temporal changes of potassium concentrations were studied as a pollution indicator. Pollution and groundwater level maps were generated using a Geostatistical program GS+ version 5.1, with the Kriging interpolation method.

\section{Modeling \\ Model description}

The model solves numerically by Gaussian Elimination iterative method the Richard's equation for saturated-unsaturated water flow and the convective dispersive equation for solute transport. The flow equation incorporates a sink term for plant uptake. The program can be used for solute and water transport for unsaturated-saturated, and variable saturated porous media. the governing solute transport equation is:

$$
\frac{\partial \theta c}{\partial t}+\frac{\partial \rho s}{\partial \theta t}=\frac{\partial}{\partial x_{r}}\left(\theta D_{i j} \frac{\partial c}{\partial x_{j}}\right)-\frac{\partial q_{i} c}{\partial x_{i}}+\mu_{w} \theta c+\mu_{s} \rho s+\gamma_{w} \theta+\gamma_{s} \rho-S c_{s}
$$

where $\mathrm{c}$ is the solution concentration $\left(\mathrm{ML}^{-3}\right)$, $\mathrm{s}$ is the adsorbed concentration(-), $\mathrm{i}_{\mathrm{w}}$ and $\mathrm{i}_{\mathrm{s}}$ are firstorder rate constants for the liquid and solid phases, respectively $\left(\mathrm{T}^{-1}\right), \tilde{\mathrm{n}}$ is the soil bulk density $\left(\mathrm{ML}^{-3}\right), \tilde{\mathrm{a}}_{\mathrm{s}}$, and $\tilde{\mathrm{a}}_{\mathrm{w}}$ are zero order rate constants for the liquid $\left(\mathrm{ML}^{-3} \mathrm{~T}^{-1}\right)$ and the solid $\left(\mathrm{T}^{-1}\right)$, and $\mathrm{Dij}$ is the dispersion coefficient tensor $\left(\mathrm{L}^{2} \mathrm{~T}^{-1}\right)$.

The input data for SWMS-3D are given in three input files, while the output results are given by seventeen output files. The model takes into account several boundary conditions. These boundary conditions include specified head (dirichilet type ) boundary conditions, specified flux (neuman type) boundary conditions, and specified gradients conditions in case of unit vertical hydraulic gradient, simulating free drainage from a relatively deep soil profile. SWMS -3D model can also implement atmospheric boundary conditions. It also can 
implement seepage face and tile drains. The same system of boundary and initial conditions can be used for solute transport boundary.

\section{Model Parameters and Runs}

The required model parameters were estimated from the literature, which include: soil, weather data, chemicals (pollutants), and simulation parameters. The model was run for $\left(\mathrm{K}^{+}\right)$for different conditions. These conditions include surface and vertical flow. Potassium will be taken as a pollution indicator.

One major run for the model was performed for potassium for $1,5,10,15,20$, and 25 years. The

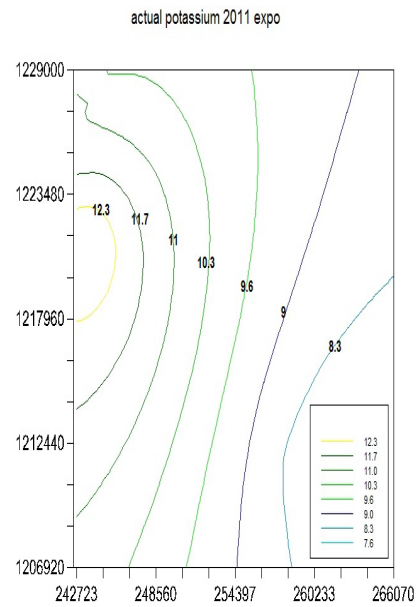

initial conditions were estimated from the year 2005, to be able to check if the model will be able to predict the concentrations of potassium in the groundwater wells of the Yarmouk basin with sound precision after the first five years. The actual and simulated concentrations of potassium in wells for year 2010 are presented in Table 1.

\section{RESULTS AND DISCUSSION}

\section{Modeling Results}

Similarity between actual data and mathematical model

Figure 2 ( $A$ and $B$ ) obtained from SWMS_3D simulating model. The two figures illustrate the

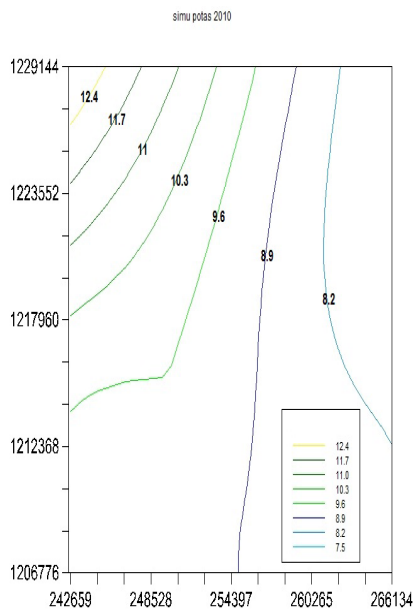

Fig. 2: Actual potassium concentration ( $\mathrm{mg} / \mathrm{l})$ in Yarmouk upper aquifer (2010),(A) and simulated potassium concentration ( $\mathrm{mg} / \mathrm{l})$ in Yarmouk upper aquifer (2010), (B)
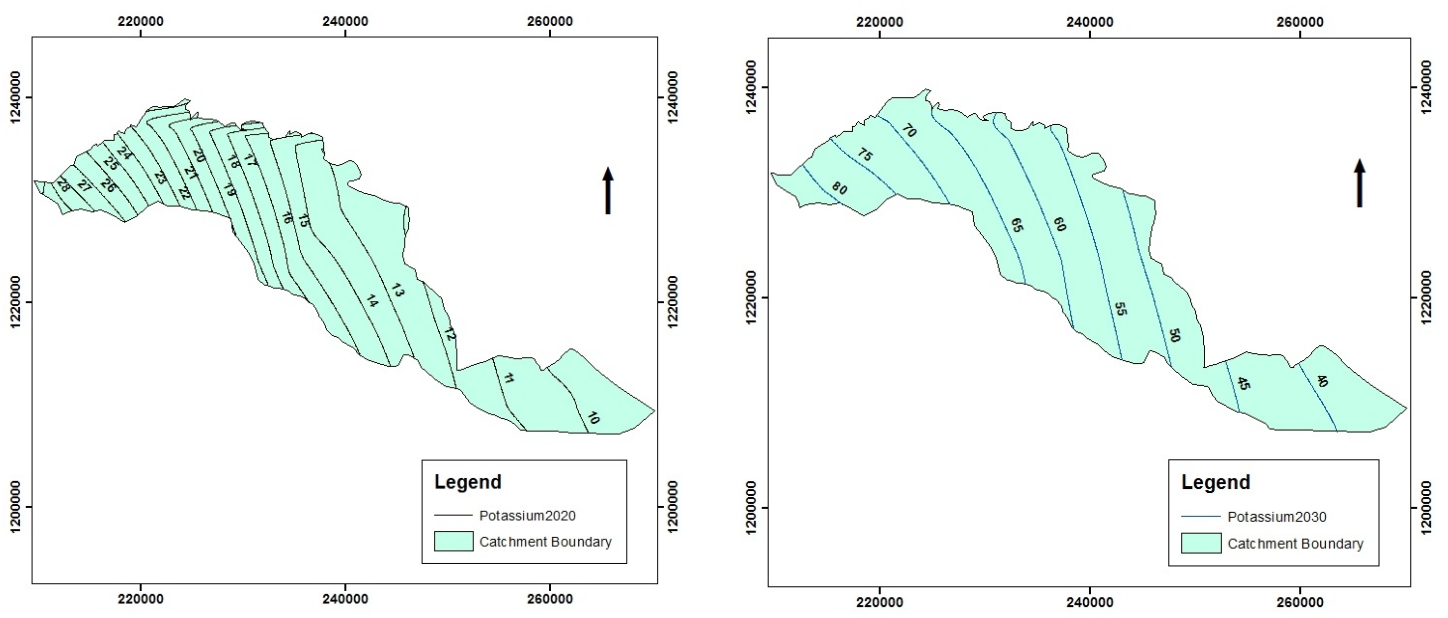

Fig. 3: Two maps showing prediction of potassium concentration in 2020 and 2030 
obvious similarity between the actual and simulated concentrations of Potassium for the year 2010.

This similarity between the actual and simulated concentrations validates the SWMS_3D model, which means that the model has been able to predict with fair accuracy the actual values of concentrations and water content of the Yarmouk upper aquifer. That will verify the other results

Table. 1:Yarmouk basin actual and simulated potassium for the year 2010.(mg/l)

\begin{tabular}{lcc}
\hline Actual $\mathbf{k}^{+}$ & Simulated $\mathbf{k}^{+}$ & Well code \\
\hline 7.4 & 7.8 & AD1037 \\
9.7 & 11.9 & AD1172 \\
9.7 & 11.9 & AD1173 \\
11.2 & 10.8 & AD1251 \\
7.3 & 8.0 & AD1262 \\
10.3 & 9.2 & AD1281 \\
11.9 & 9.7 & AD1295 \\
11.9 & 9.7 & AD1296 \\
7.3 & 7.3 & AD3004 \\
9.6 & 12 & AD3008 \\
12.5 & 18.9 & AD1239 \\
\hline
\end{tabular}

of future values for years 2020, 2030. Figure 3, illustrates future predictions of model

\section{DISCUSSION}

A phenomenon can be observed from Figure.3: that is the increase in potassium concentrations for the decade ahead (2020). But it can be seen easily the tremendous rise between 2020-2030, which can be either attributed to intensive cultivation that exhaust the natural ecological balance through ever increasing use of organic and chemical fertilizers. Where both are sources of potassium, or to over abstraction of groundwater which enhances potassium and other pollutants concentrations in groundwater of upper aquifer. Also it can be attributed to increasing urban and orthopogenic activities with possibilities of potassium and other pollutants leakage from nearby wastewater treatment plants or solid waste disposal sites. In particular during floods or when the leachates or liquid loads exceeds evaporation of infiltration potentials, or due to some or to all of the mentioned reasons. Figure 4, illustrates locations of the wells used in the model as well as springs in the Yarmouk upper aquifer.

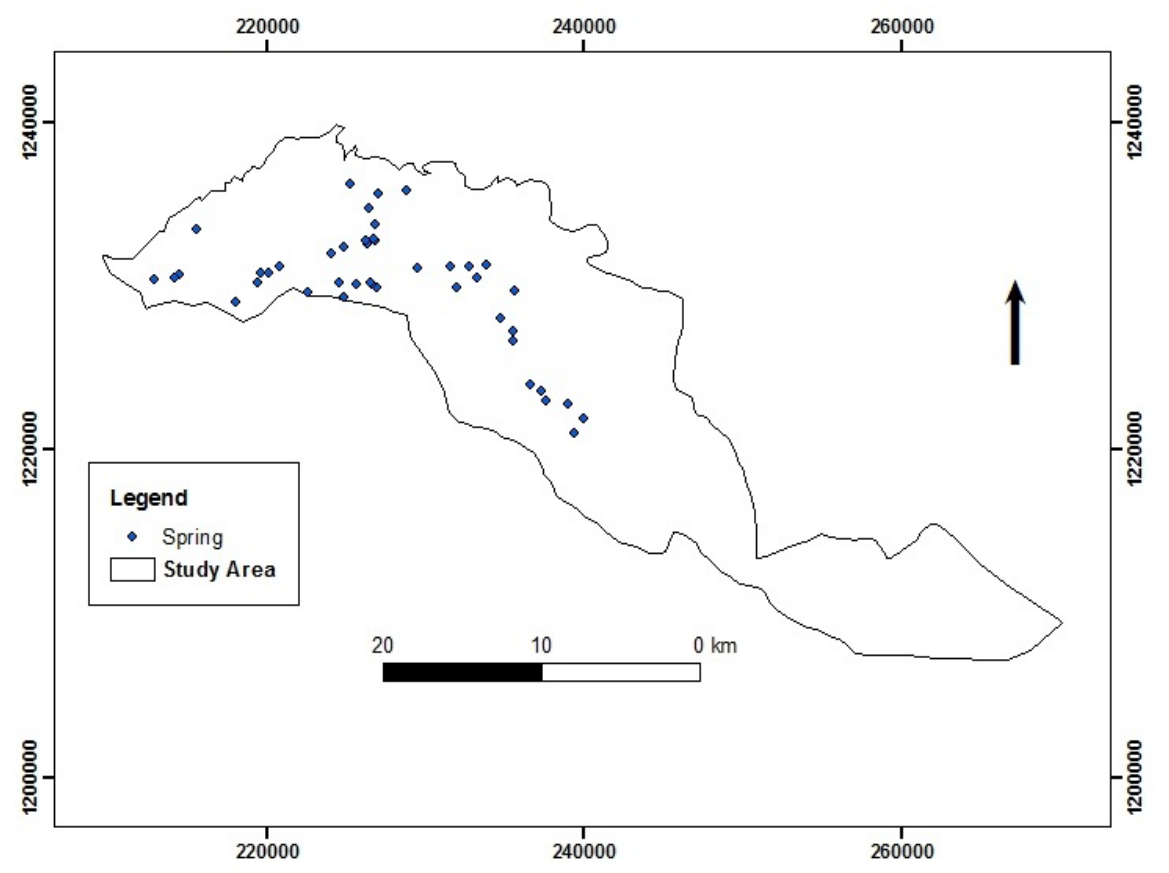

Fig. 4: locations of springs and wells used in simulation of potassium concentrations 


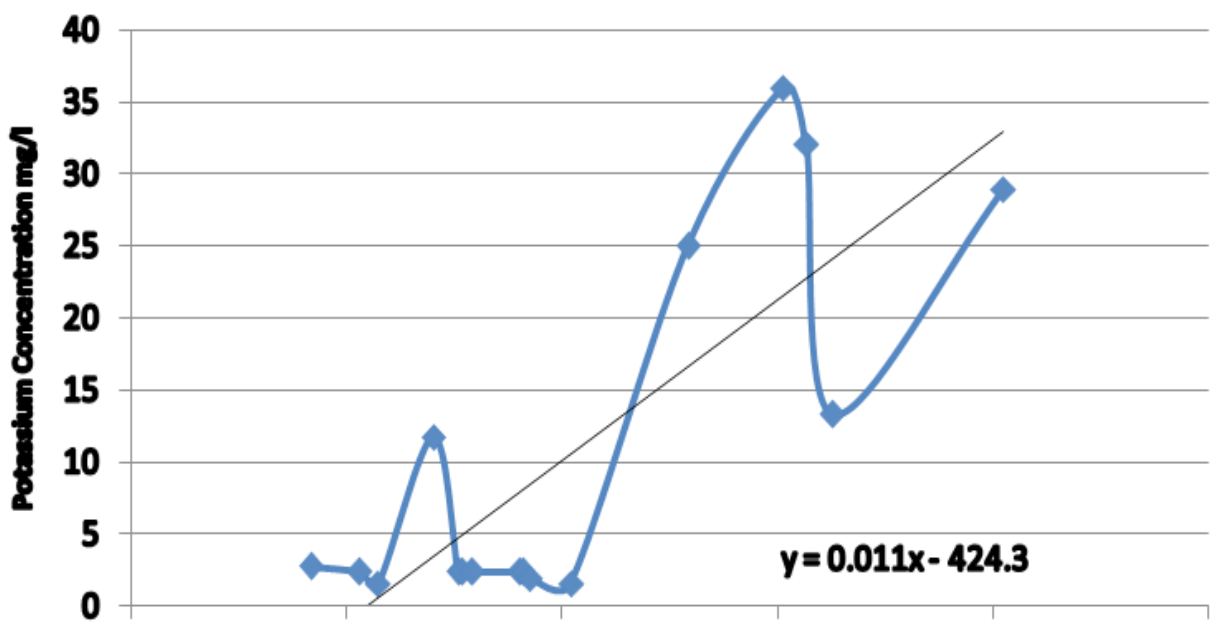

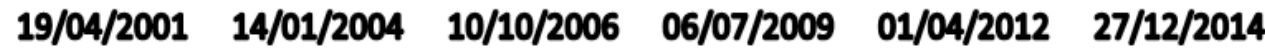

Fig. 5: Temporal variation of potassium in well AD 1295 for the period, (2004-2012)

\section{Temporal Trend and Temporal Variation}

Figure 5, shows clearly, that potassium concentrations are increasing rapidly for the observation period (2004-2012) which agrees with the results of potassium concentrations obtained by SWMS_3D model for the simulation period (2006-
2030). And it is obvious seen that, the concentration values of potassium had increased drastically starting from the year 2007. This indicates that the pollution has increased at that period, which could be attributed to increase of water abstraction or increased agricultural activities.

\section{REFERENCES}

1. Abu-Jaber, N. and Kharabsheh, A., Groundwater origin and movement in the upper Yarmouk Basin, Northern Jordan. Environ. Geol., 54: 1355-1365 (2008).

2. Al-Taani, A., Batayneh, A., El-Radaideh N., AlMomani I., and Rawabdeh A., Monitoring of Selenium Concentrations in Major Springs of Yarmouk Basin, North Jordan, World Applied Sciences Journal, 18(5): 704-714 (2012).

3. Awawdeh, M., and Jaradat, R., Evaluation of aquifers vulnerability to contamination in the Yarmouk River basin, Jordan, based on DRASTIC method Springer, pp.273-282 (2009).

4. Batayneh, A., Heavy Metals in Water Springs of the Yarmouk Basin, North Jordan and their Potentiality in Health Risk Assessment. International Journal of Physical Sciences, Research paper, 5 (2010).

5. Chilton J., Assessment of Aquifer pollution vulnerability and susceptibility to the impacts of abstraction. Protecting groundwater for health: managing the quality of drinking-water sources. WHO drinking-water quality series. IWA, London, pp 199-239 (2006).

6. Denny, E., Donnelly, K., McKay, R., Ponte, G., and Uetake, T., Sustainable Water Strategies for Jordan. International Economic Development Program, Gerald R. Ford School of Public Policy, University of Michigan, Ann Arbor (2008).

7. Jordan Meteorological Department (JMD), Annual report, Ministry of Transport. Amman, Jordan (2010).

8. Kolahchi, Z., and Jalili, M., Effect of water quality on the leaching of potassium from sandy soil, Journal of Arid Environments, 68; 624-639 (2006).

9. Ministry of Water and Irrigation (MWI), Jordan Institution for Standards and Metrology: 
Drinking Water Standard JS 286:2008, Fifth Edition, in Arabic, retrieved on May 26, 2012.

10. Nortcliff, S., Carr, G., Potter, R.B., and Darmame, K., 2008. "Jordan's Water Resources: Challenges for the Future." Geographical Paper No. 185, The University of Reading, United Kingdom.
11. Obeidat, M., Ahmed, Y., Hamouri N., Adnan, M. , and Athamneh, F., Assessment of Nitrate contamination of Karst springs, BaniKanana, Northern Jordan, Revista Mexicana de CienciasGeologicas, 25(3): 426-437 (2008).

12. World Health Organization (WHO), Guidelines for drinking water quality, Geneva-Switzerland (2011). 